\title{
Geotechnical controls on a steep lateral moraine undergoing paraglacial slope adjustment
}

\author{
Alastair M. Curry ${ }^{1 *}$, Tim B. Sands ${ }^{2}$, and Philip R. Porter ${ }^{2}$ \\ ${ }^{1}$ Department of Geography and Land Management, Royal University of Phnom Penh, \\ Confederation de la Russie Boulevard, Phnom Penh, Cambodia \\ ${ }^{2}$ Division of Geography and Environmental Sciences, University of Hertfordshire, \\ Hatfield AL10 9AB, U.K \\ *Correspondence to: Alastair M. Curry; email: currys@omf.net
}

Abbreviated title: Steep moraine slopes

\begin{abstract}
Sustained post 'Little Ice Age' retreat of the northern lobe of the Feegletscher, Valais, Switzerland, has exposed lateral moraines that show pronounced over-steepening on the upper proximal slopes, with upper slope segments displaying angles of up to $c .70^{\circ}$. Paraglacial processes have eroded gullies into the upper slope segments, and associated debris flow deposits result in lower angles of between $34^{\circ}$ and $25^{\circ}$ in the mid-slope and slope-foot zones respectively. In order to assess the geotechnical properties of morainic sediments that permit development of quasi-stable, over-steepened slope segments, a standard suite of geotechnical measures were applied to samples of Feegletscher moraine sediments. Shear box testing yielded angles of friction ranging from $35^{\circ}$ for loose samples to $52^{\circ}$ for dense samples. Although the heterogeneous nature of moraine deposits makes laboratory testing of the whole size range of in situ sediments impractical, shear box test results imply that in situ upper slope angles exceed the angles of friction of moraine sediments by $26-40^{\circ}$. We are unable to replicate angles of friction in shear box tests that correspond to in situ angles of the upper slope sections measured in the field. However, we suggest that distal dipping mica-schist clasts may play an important role in permitting high angle slope stability. Quasi-stable storage of glacigenic sediments in high-angle moraine sequences over decadal timescales has
\end{abstract}


implications for understanding the period following deglaciation over which paraglacial reworking and redistribution of sediments may operate.

\section{Introduction}

Glacier retreat triggers the progressive modification of glacial sediments, landforms, landscapes and landsystems through their exposure to non-glacial earth-surface processes and conditions. In recently-deglaciated mountain areas, a wide range of these paraglacial processes are responsible for the release, reworking and redeposition of large quantities of unstable glacigenic sediment over a wide range of timescales (Ballantyne, 2002a). Steep, sediment-mantled valley slopes, for example, are eroded by rapid mass movement processes, often creating a landsystem of intersecting gullies, coalescing debris cones and valley-floor deposits of reworked sediment in a matter of decades (e.g. Ballantyne and Benn, 1994; Ballantyne, 1995; Curry, 1999; Curry et al., 2005). These phenomena also pose a risk to inhabitants and infrastructure in deglaciated valleys, some of which are frequented by large numbers of visitors (e.g. INSERT). While recent studies have focused attention on the processes, rates, and sedimentological and morphological consequences of this activity, few have specifically considered the geotechnical characteristics of sediments that may be susceptible to failure by paraglacial processes.

High-angle, gullied lateral-terminal moraines are a common feature of deglaciating landsystems in the European Alps and elsewhere. Their morphology and steep gradient are strong conditioning factors for rapid and extensive paraglacial slope adjustment (e.g. Curry, 2000; Curry et al., 2005). Although such lateral-terminal moraines are eroded rapidly following deglaciation, their upper slopes commonly retain a pronounced oversteepened form, at least during the early period of deglaciation and associated paraglacial modification. The detailed geotechnical characteristics of lateral-terminal moraines that permit them to stand in a quasi-stable state at high angles have yet to be adequately explained, however. This lack of detailed understanding arises partly due to the difficulties of accessing steep moraine slopes that are subject to regular paraglacial activity (such as debris flows and release of clastic debris from the fine-grained matrix) and the problems of replicating in situ conditions when undertaking geotechnical analysis in the laboratory. This research applies geotechnical methods to a lateral-frontal 
moraine sequence in an attempt to explain the geotechnical properties of glacigenic sediments that may allow them to stand at high angles in a quasi-stable form.

Lateral-frontal moraines are formed as debris falls, slumps, slides or flows down the ice surface and accumulates around the glacier margin (e.g. Small, 1983; Owen and Derbyshire, 1989; Owen, 1994). The relative balance of debris supply from supraglacial and valley-side sources will affect the resultant detailed moraine morphology and sedimentary facies, while successive ice advances may result in superimposition of lateral-frontal moraine structures (Bennett and Glasser, 1996). If the glacier remains in a stable position, the accumulation of dumped material often produces a wedge-shaped moraine with strong fabric and crude internal bedding dipping away from the glacier at angles of $10^{\circ}-40^{\circ}$ (Small, 1983, Bennett and Glasser, 1996). However, the ice-proximal parts of lateral-frontal moraines tend to be structurally complex, reflecting widespread collapse and reworking following removal of ice support, together with ice-marginal glacifluvial activity. Moreover, melt-out of buried ice and postglacial gravitational reworking may destroy bedding. Sediment facies commonly consist of stacked diamictons with variable clast content intercalated with thin sand and gravel layers, reflecting intermittent glacifluvial deposition and reworking (Benn et al., 2005). Most diamict facies are sandy boulder gravels containing predominantly angular debris from passive transport of rockfall material, though more rounded clasts may be found within lateral moraines where a higher proportion of basal zone debris is delivered to the terminus (Matthews and Petch, 1982), or where proglacial sediment is entrained during glacier advance (Slatt, 1971). Where valley-constrained glacier termini repeatedly occupy similar positions, large, multi-crested lateral moraines may form, reflecting episodic aggradation separated by periods of erosion or non-deposition. Complex depositional histories may be preserved in the internal moraine structure, with multiple depositional sequences bounded by erosion surfaces. Periods of non-deposition may be indicated by buried palaeosols (e.g. Röthlisberger et al, 1980).

The extent, conditioning factors, morphological consequences and rates of recent paraglacial reworking of sediment at this site are considered in detail elsewhere (Curry et al., 2005), while geotechnical investigation has previously been undertaken at this locality (Whalley, 1975). Whalley applied shear test results from the nearby Allalingletscher lateral moraine to the similar form of moraine slopes at Feegletscher Nord in an attempt to explain the preservation of pronounced over-steepening on the upper moraine slopes. Here we report the results of geotechnical testing of samples 
drawn directly from the Feegletscher Nord moraine sequence.

\section{Study area}

Investigation of the paraglacial modification of valley-side sediment-mantled slopes was undertaken in August 2001 and September 2006 in the forefield of the Feegletscher Nord (46 $\left.06^{\prime} \mathrm{N}, 7^{\circ} 54^{\prime} \mathrm{E}\right)$, in the Saaser valley, Valais, Switzerland (Figure 1). The Feegletscher is a small $\left(<10 \mathrm{~km}^{2}\right)$ ice-field outlet glacier which descends from an altitude over 4000 m.a.s.l on the eastern flank of the Mischabel to a terminus at $c .2200$ m.a.s.l (as of September 2006). The front of the Feegletscher divides into two distinct tongues; a heavily crevassed icefall characterises the top of the wider southern lobe snout area. The northern lobe (hereafter referred to as Feegletscher Nord) is also heavily crevassed in the upper reaches, but becomes increasingly constrained and narrowed by steep rock-walled topography in its lower reaches. Both lobes are orientated in a northeasterly direction. The site is dominated by Bernard nappe mica-schists, with serpentinite, amphibolite and quartzite (Swiss Geological Commission, 1980; Hsü, 1995). It experiences the inner alpine, relatively dry climate of the Valais surrounded by high mountains, with an estimated $800-1200 \mathrm{~mm}$ annual precipitation and mean annual temperatures of approximately $+1.5^{\circ} \mathrm{C}$ (Swiss Meteorological Survey, Zürich). The lower limit of discontinuous permafrost in Valais is $c .2350 \mathrm{~m}$ for north-facing slopes and $2650 \mathrm{~m}$ for south-facing slopes (Lambiel, personal communication, 2003).

The site was deglaciated by $c .9 \mathrm{ka} \mathrm{BP}$, but was repeatedly reoccupied by ice during the Holocene (e.g. Röthlisberger and Schneebeli, 1979; Röthlisberger et al., 1980). Feegletscher Nord reached its 'Little Ice Age' maximum position at AD 1818, since when it has experienced overall retreat of $c .1200 \mathrm{~m}$ and lowered $c .90 \mathrm{~m}$ (Bircher, 1982; GK/SANW \& VAW/ETZH, 2005). After a slight re-advance during the 1970s and 1980s, annual retreat of the Feegletscher Nord has been sustained since 1989 (Schnyder, personal communication, 2006).

The forefield area displays marked within-valley asymmetry, with much larger moraine volume on the northern side reflecting increased debris supply from extensive rockwalls on that side of the valley (Figure 1). On the northern side of the forefield, the pattern of glacier thinning and retreat has exposed steep glacigenic deposits composed of a stacked, multi-crested, lateral moraine, which has subsequently been locally 
reworked, with deep, intersecting gullies forming on most upper slopes at or just below the moraine crest and cones or sheets of reworked sediment accumulating at the slope foot (Figure 2).

The dominant agent of reworking of glacigenic sediment at this site is debris flow activity and translational sliding (Curry et al., 2005), triggered by rainstorms and snowmelt. There is further, localised evidence of snow/slush avalanches, falls and surface wash. The Feevispa outlet stream has incised the lateral-terminal moraine in the south-east, and glacifluvial gravel and sand has accumulated on the valley floor within the proximal proglacial zone.

\section{Moraine morphology and evolution at Feegletscher}

The stacked lateral moraine on the northern valley side is $c .60-120 \mathrm{~m}$ high, $c .700 \mathrm{~m}$ long (down-valley), and has a summit altitude which descends down-valley from 2060 $\mathrm{m}$ in the west to $1940 \mathrm{~m}$ in the east, considerably below the lower limit of discontinuous permafrost. A pronounced step is visible part-way along the moraine crest, at c. 2020 m.a.s.l. At this point, a separate ridge diverges to the north-east, and represents the AD 1818 ice limit. Above (west of) this step, proximal slope height exceeds $100 \mathrm{~m}$, but below it the height of the proximal slope is less than $70 \mathrm{~m}$. Historical photographs suggest that the moraine may have been overtopped at this point during the 1890s.

The distal slope is fully vegetated, relatively stable (except for some surface creep as evidenced by curvature of tree trunks) and rests at a gradient of $c .33^{\circ}$. In contrast, the proximal slope is largely unvegetated, and steeper, although gradient is more variable, with the most recently-deglaciated terrain generally steeper $\left(<80^{\circ}\right)$ than the older ground $\left(<50^{\circ}\right)$. On the oldest terrain, the most mature cones and sheets of reworked debris extend almost to the moraine crest and support a partial grass cover.

Previous investigations of the temporal pattern of moraine slope adjustment at Feegletscher Nord indicate that following an initial period of gully incision, intervening gully divides are consumed through gully widening, resulting in progressive slope stabilisation and levelling of inter-gully relief within 80 years (Curry et al., 2005). Thus a dynamic landsystem of deep gullies, sharp arêtes and nascent debris cones is being replaced by one of increasingly vegetated coalescing cones and debris aprons, levées, lobes and low-relief scars. The resultant gullied moraine complex is morphologically 
similar to lateral moraine sequences observed elsewhere in the European Alps (e.g. Curry et al., 2005).

\section{Field methods}

Initial assessment of the extent of paraglacial reworking of glacigenic sediment comprised detailed geomorphological mapping on 1:5,000 scale base maps, produced with the aid of ground and aerial photographs. Access to steep, potentially unstable moraine slopes is problematic. In particular, assessing the slope angles of upper slope units (interfluves and gullies) that stand at angles of up to $80^{\circ}$ is fraught with difficulty. 50 upper slope section angles were therefore measured by attaching a compass clinometer to a metre rule and placing this over the edge of the cliff at multiple locations along the moraine crest. Compass-clinometer measurements were also made at multiple locations along the moraine on the accumulated lower-angle debris cones. Although these lower slope units were sufficiently accessible to allow the use of more accurate surveying techniques, in order to maintain a constant level of accuracy/error, compassclinometer measurements were utilised throughout.

Diamict facies exposed include sandy boulder gravels containing coarse, angular and sub-angular material. Distal-dipping of large boulders is clearly evident in the upper moraine slopes, exposed by recent erosion (Figure 3), though for practical reasons of accessing steep, potentially unstable upper slope units in situ fabric could not be quantitatively assessed. Clearly, the coarsest particles are impractical to sample and test using standard geotechnical laboratory techniques. The sedimentological size characteristics of eleven samples of in situ till deposit, each weighing $1 \mathrm{~kg}$ were assessed in terms of fine-fraction $(<8 \mathrm{~mm},-3 \quad \Phi)$ particle-size distributions representative of the finer matrix material within the moraine. Ten samples of massive, poorly sorted, compacted diamicton, spaced $50 \mathrm{~m}$ apart along the crest of the moraine ridge were extracted using a trowel, labelled 1-10 from the west to east (FT1-10, Figure 1). Each of these samples was removed $0.2 \mathrm{~m}$ below the ground surface, c. $1 \mathrm{~m}$ from the proximal slope edge. Sample locations 1-4 are located above a clear step in the moraine crest at an altitude of 2020 m.a.s.1, while samples 5-10 are located east of this point. At each of these ten sediment sampling locations, an in situ density test was carried out to BS1377: Part 9: 1990 using the 'sand replacement method'. These in situ measurements 
were carried out for comparison with the densities determined for samples used in the shear tests outlined below. The procedure involved excavating a $0.1 \mathrm{~m}$ diameter hole to a depth of $0.1 \mathrm{~m}$ in a levelled area of moraine, using a metal tray with a hole in the middle as a proforma, and weighing the excavated material. A pre-weighed pouring cylinder filled with sand of known density was then placed over the hole, and the sand released into the hole to fill it. The cylinder was weighed again and the mass of sand poured into the hole calculated. The volume of the hole was determined from the mass of sand poured, and the bulk density of the moraine calculated. The moisture content of a small sample of material taken from the hole was then determined in order to calculate the dry density of the moraine.

Finally, a bulk sample of moraine material weighing $18 \mathrm{~kg}$ was removed from a depth of $0.2 \mathrm{~m}$ on the moraine crest at a point $80 \mathrm{~m}$ south-east of sample 10, for laboratory shear tests. An eleventh particle-size sample weighing $1 \mathrm{~kg}$ was taken from this bulk sample, for granulometric analysis of material finer than $8 \mathrm{~mm}(-3 \Phi)$, as well as clast lithological and form analysis.

\section{Laboratory procedures}

To prepare samples for sieving, initial disaggregation was undertaken by prolonged (3 hours) agitation in a $4 \%$ solution of sodium hexametaphosphate. The particle size distribution of fine gravel to very fine sand-sized material was determined by wet sieving for each of the eleven till samples using wet sieving, with weight per fraction calculated as a percentage of the total. Volume of material finer than $63 \mu \mathrm{m}(4 \mathrm{\Phi})$ in each sample was quantified by a Malvern Instruments laser particle size analyzer, and the results converted into \% weight data. 167 clasts coarser than $10 \mathrm{~mm}$ were sampled from the bulk sediment, described, identified for lithology, and their three principal axes measured to calculate flatness and elongation ratios (Zingg, 1935). Aggregate clast shape was also calculated in terms of the percentage of clasts with $c: a$ axial ratios $\leq 0.4$ $\left(\mathrm{C}_{40}\right)$ and $\leq 0.5\left(\mathrm{C}_{50}\right.$; Ballantyne, 1982), and angularity expressed as the percentage of very angular plus angular clasts (RA; Benn and Ballantyne, 1994).

The aim of the direct shear tests was to determine the effective angles of friction for the matrix material for a range of densities and fabric orientations. These values could then be compared with the variety of in situ angles of repose, as indicated by the 
proximal and distal slopes of the moraine, and the redeposited debris at the base of the proximal slope.

To prepare a sample with fabric at a high angle to the shear surface, either an undisturbed sample has to be obtained from the moraine, or a reconstituted sample has to be manufactured. The former is virtually impossible because of the lack of cohesion, suction or cement, and the presence of large clasts. The latter method is also impractical because a $300 \times 300$ sample would have to be prepared using a procedure to place flat clasts horizontally and the entire sample would then have to be rotated through $90^{\circ}$ and placed into the shear box intact.

Clearly, a limitation of the shear box tests is that the material (and its fabric) has been disturbed, and then reconstituted within the shear box at densities that may differ from in situ densities. Furthermore, the range of matrix particle sizes does not include particles coarser than gravel size, which may affect the shear strength of the reconstituted moraine samples. The two halves of the shear box control the formation of the shear surface or zone. However, the use of a large shear box $(300 \times 300 \mathrm{~mm})$ is the best available method for laboratory determination of the material shear strength parameters.

A series of direct shear tests using a large shear box $(300 \times 300 \mathrm{~mm})$ were carried out on an air-dried sample of the moraine matrix material, using the method in BS1377: Part 7, 1990. For the first series of three tests the lateral moraine sample was loosely placed into the shear box in three layers, to simulate the undisturbed distal and debris slopes. In a second series of three tests, an air-dried sample of material was compacted into the large shear box in three layers, each layer compacted for 60 seconds with a Kango vibrating hammer and plate rammer. The compaction of the sample is intended to simulate glacial compaction of the moraine during successive advances of Feegletscher Nord. A series of vibrating hammer compaction tests were carried out to BS 1377: Part 4: 1990, to determine the maximum dry density and optimum moisture content of the bulk sample, for comparison with the densities achieved in the shear box. For a third series of shear box tests, the air-dried sample was compacted into the large shear box in 3 layers and each layer compacted for 30 seconds with a Kango hammer and plate rammer. After compaction of the second layer 25 gravel-size flat clasts were placed in 5 rows with their $c$-axes parallel to the direction of shear, to partly simulate the distally-dipping fabric of supraglacially-derived material emplaced by dumping and gravity-flow deposition at the glacier margins (cf. Small, 1983). In each series of tests 
the air-dried sample was subjected to three normal stresses equivalent to the likely in situ stresses within the near-surface sediments of the lateral moraine, based on the densities measured in the field, and then sheared at a rate of $1 \mathrm{~mm} \mathrm{~min}^{-1}$. The lowest normal stress that could practically be applied by the shear box was used to simulate shear near the surface.

The effective angle of friction was determined from the Mohr-Coulomb failure criterion:

$$
\tau_{\mathrm{f}}=\mathrm{c}^{\prime}+\sigma_{\mathrm{n}}{ }^{\prime} \tan \phi^{\prime}
$$

where $\tau_{\mathrm{f}}$ is shear strength, $\mathrm{c}^{\prime}$ is effective apparent cohesion, $\sigma_{\mathrm{n}}{ }^{\prime}$ is effective normal stress, and $\phi^{\prime}$ is effective angle of friction. Assuming that the effective apparent cohesion of the material is zero, the effective angle of friction is therefore:

$$
\phi^{\prime}=\tan ^{-1} \tau_{\mathrm{f}} / \sigma_{\mathrm{n}}{ }^{\prime}
$$

\section{Results}

The proximal slope can be subdivided into three major slope elements, consisting of an over-steepened top slope, a middle gullied slope and a lower-angled debris sheet beneath (Figure 4). The middle gullied slope section can be further subdivided into upper, middle and lower inter-gully sidewall slopes and gully floor slopes. Results of slope measurements made on the Feegletscher Nord moraine are shown in Figure 5. The median slope angle of the undisturbed and heavily vegetated distal slope is $33^{\circ}$. The median angle of the top proximal slope units was $63^{\circ}$. Median slope angles of the upper, middle and lower inter-gully sidewalls were $73^{\circ}, 64^{\circ}$ and $74^{\circ}$ respectively. The average measured proximal debris cone slopes were $47^{\circ}, 34^{\circ}$ and $25^{\circ}$ for the upper, middle and lower sections respectively.

Results of in situ dry density measurements are shown in Table 1. Values range from 0.84 to $2.34 \mathrm{Mg} \mathrm{m}^{-3}$ with an average of $1.70 \mathrm{Mg} \mathrm{m}^{-3}$. The maximum dry density and optimum moisture content values of the bulk sample, obtained from the vibrating hammer compaction tests, were $2.25 \mathrm{Mg} \mathrm{m}^{-3}$ and $7.9 \%$ respectively. In situ dry densities derived from the shear box samples range from $1.91 \mathrm{Mg} \mathrm{m}^{-3}$ for the loosely packed 
sample, 2.01-2.20 $\mathrm{Mg} \mathrm{m}^{-3}$ for the densely packed sample and 2.12-2.16 $\mathrm{Mg} \mathrm{m}^{-3}$ for the densely packed sample with partial perpendicular fabric (Table 2).

The particle size distributions for the material finer than $8 \mathrm{~mm}(-3 \Phi)$ of the $10 \mathrm{in}$ situ moraine samples and the single bulk moraine sample are shown in Figure 6. Particle size analysis shows a generally poorly sorted, well-graded range of particle sizes, with clay size particles making up less than $1 \%$ of material finer than $8 \mathrm{~mm}$ in all moraine samples. $94 \%$ of clasts sampled coarser than $10 \mathrm{~mm}$ were mica-schist, $5 \%$ were quartz, $<1 \%$ were mylonite and $<1 \%$ serpentinite. Clasts were found to be generally subangular (83\%; average RA index $=84)$, and smooth $(99 \%)$. Clast form is described by $\mathrm{C}_{40}$ and $\mathrm{C}_{50}$ indices of $62 \%$ and $85 \%$, respectively, indicating a slabby or elongate form typical of supraglacially-transported clasts (Benn and Ballantyne, 1994). Following Zingg's clast form method, $66 \%$ of the sampled particles were found to be flat (Figure 7). Of the remainder, $14 \%$ were equidimensional, $13 \%$ flat and elongate, and $7 \%$ elongate. The average flatness and elongation ratios were 0.506 and 0.760 respectively, which indicates that the average clast form is flat (Zingg, 1935). The material finer than 10 $\mathrm{mm}$ also contains mica flakes, which by their nature are flat in form.

The shear stress versus displacement and shear stress versus normal stress graphs for the well graded muddy sandy gravel bulk moraine sample are shown in Figure 8. The effective angle of friction of the loosely packed sample (hereafter referred to as "loose") ranges from $35^{\circ}$ to $36^{\circ}$, with an average of $35^{\circ}$ (Table 2). The peak effective angle of friction obtained for the compacted moraine sample (hereafter referred to as "dense") ranged from $38^{\circ}-52^{\circ}$, with an average of $44^{\circ}$, while peak effective angle of friction obtained for the densely packed fabric samples (hereafter referred to as "dense fabric") ranged from $47^{\circ}-49^{\circ}$ with an average of $48^{\circ}$. Critical effective angles of friction were $35^{\circ}, 34^{\circ}$ and $42^{\circ}$, for the loose, dense and dense fabric samples respectively. The average dry densities of the loose, dense and dense fabric samples determined at the end of shear box testing were $1.91,2.17$ and $2.13 \mathrm{Mg} \mathrm{m}^{-3}$ respectively. These are all within the range of the in situ densities shown in Table 1.

\section{Discussion}

This research tests the hypothesis that the angles of friction obtained from shear tests for samples of the lateral moraine prepared to different densities and fabrics should be 
similar to the natural angles of repose of the lateral moraine, assuming shallow translational failure. The grading of the moraine material support field observations that suggest the type of failure is likely to be shallow translational sliding, flow and individual clast slide and/or fall, rather than deep seated rotational slip, because of the very small percentage of clay-sized particles (cf. Selby, 1993). Moreover, well graded, imbricated and overlapping clasts prevent a discrete deep-seated rotational failure surface developing. Translational failure of an 'infinite' cohesionless soil slope is assumed to occur on a plane parallel to the ground surface, at shallow depth. The factor of safety $\mathrm{F}$ of the slope at the point of translational failure along a potential shear surface is commonly described as:

$$
\mathrm{F}=\tau_{\mathrm{f}} / \tau=\left[1-\left(\mathrm{u} / \gamma \mathrm{z} \cos ^{2} \beta\right)\right] \times\left[\tan \phi^{\prime} / \tan \beta\right]=1
$$

where $\tau=$ shear stress, $\mathrm{u}=$ pore-water pressure, $\gamma=$ unit weight of soil, $\mathrm{z}=$ depth of failure surface, and $\beta=$ slope angle.

Assuming that the pore spaces within the moraine are unsaturated and that $\mathrm{u}=0$, then equation (3) yields:

$$
\beta=\phi^{\prime}
$$

The gradient of the ground surface is therefore equal to the effective angle of friction of the material. If there is a pre-existing slip surface such as that which may exist between flat clasts with a distinct fabric parallel to the ground surface, then the mobilized effective angle of friction would be equal to the critical effective angle of friction, $\phi^{\prime}$ crit and equation 4 becomes:

$$
\beta=\phi^{\prime}{ }_{\text {crit }}
$$

This appears to be true for the distal and middle proximal debris slopes, which because of their general flat clast form, are orientated parallel to the slope and have undergone significant shearing during their formation, and so would be expected to be close to the $\phi^{\prime}$ crit for loose and dense samples. In fact the median slope angles of $33^{\circ}$ and $36^{\circ}$ measured for the distal and middle proximal debris slopes respectively, and those 
obtained by Whalley (1975) of $35^{\circ}$, compare well with the $\phi^{\prime}$ crit for loose and dense samples of $35^{\circ}$ and $34^{\circ}$ respectively.

However, the average peak angles of friction obtained from shear tests on samples of the lateral moraine was $44^{\circ}$ for the dense sample and $48^{\circ}$ for the dense sample with partial perpendicular fabric. These angles are considerably lower than the maximum median slope angle of $74^{\circ}$, and those found at this site by Curry et al. (2005) and Whalley (1975) of $69^{\circ}$ and $70^{\circ}$ respectively. This may reflect the fact that the majority of the flat mica-schist clasts in the reconstituted sample were likely to be orientated subhorizontally in the shear box and therefore their fabric was parallel or sub-parallel to the shear surface. The silt- and sand-sized material, made up of mainly mica particles, may also naturally lie flat when placed in the shear box, as do the gravel-sized particles which were mainly flat mica-schist clasts. In the upper proximal slopes of the lateral moraine, shear of the material near the surface would be at a high angle to the generally distal-dipping imbricated clasts. Therefore for shallow translational shear to occur parallel with the proximal slope surface, shear would probably be between distallydipping flat clasts in addition to shear of some intact clasts. The shearing resistance along this potential shear surface would be significantly increased by the shear surfaces between clasts being at an oblique angle to the slope and by clast intact shear strength. For shear failure to occur, therefore, significant dilation of the material is required. This dilation phenomenon is recognized in dense soils, which experience volumetric increase when sheared, until a peak shear stress is reached, followed by a reduction in the rate of dilation until a critical state is reached. At low normal effective stresses many soils exhibit 'dense' characteristics. In the shear box the material dilates and the platen rises at the angle of dilation, $\psi$. Although the shear surface is horizontal, it can be conceptualised that the microscopic inter-granular shear planes are inclined at an angle of $\psi$. Therefore, the effective angle of friction being measured is:

$$
\phi^{\prime}=\phi^{\prime}{ }_{\text {crit }}+\psi
$$

This is similar to shear between rock surfaces which are inclined at an angle $i$, to the direction of shear (Hoek and Bray, 1981). Given the presence of interlocking asperities along rough rock-mass discontinuity surfaces, shear stresses along these 
partings are often inclined to the overall applied shear stress direction. In this case the relationship between applied shear and normal stresses is:

$$
\tau_{\mathrm{f}}=\sigma_{\mathrm{n}} \tan (\phi+\mathrm{i})
$$

It can be assumed that the moraine, a well graded material from silt to boulders, behaves somewhere between a soil and a weak, highly-fractured rock mass. The observed stratification and fabric within the undisturbed moraine might suggest that the geotechnical properties are more closely aligned with those of a highly-fractured rock mass than a soil. If it is assumed that the stability of the upper proximal slope is governed by shallow translational failure and equation 4 is rewritten in terms of the angle of inclination, then:

$$
\beta=\phi+\mathrm{i}
$$

Hoek and Bray (1981) present a number of values of $(\phi+i)$ from several authors for different rock types and discontinuity surfaces at low normal stresses, ranging from $66^{\circ}$ to $80^{\circ}$, with an average of $72^{\circ}$. This value is close to the gradients of the proximal upper and lower inter-gully sidewall slopes, which have median angles of $73^{\circ}$ and $74^{\circ}$ respectively. Consequently, it seems plausible to suggest that the stability of steep, relatively undisturbed upper proximal slopes of the Feegletscher Nord moraine may be controlled by shallow translational failure, with inclined shear stresses and resulting dilation between the generally distally-dipping clasts (Figure 9). Indeed, we consider that the major cause of the steep slopes at Feegletscher Nord likely reflects the distaldipping fabric, whose stabilising role is significantly enhanced by the generally flat form of the mica-schist clasts. Imbrication of these flat form clasts inhibits shallow translational shear on the proximal slopes and hence permits retention of steep slope angles. A further, secondary, temporary slope stabilising effect may be the natural 'buttressing' of the moraine material caused by the creation of inter-gully slopes through incision of adjacent gullies, prior to their erosion and removal, although this effect cannot be substantiated without further field investigation.

A possible alternative explanation for the difference between maximum observed slope angles and peak angles of friction concerns the role of cementing and suction 
(Whalley, 1975). Coarse-grained particles such as gravel and sand-sized material may be held together by the intermolecular bonds of cementing precipitates such as silica, calcium carbonate, and iron oxides, and by bridges of clays. The moraine material observed by the authors, however, was found to be friable and relatively easily broken up by finger pressure, suggesting a lack of suction and/or cementation. There is unlikely to be much cementing due to the young age of the deposit and the lack of evidence for groundwater flow carrying minerals that could provide cement. There may be some temporary suction pressure holding the fine clasts together during dry periods following evaporation of infiltrated precipitation, because of their flat shape and the silt- and sandsized matrix. This may explain the weak surface 'crust' that is sometimes observed, which holds finer particles together in larger agglomerates. This suction is very difficult to measure in situ because of the well-graded nature of the sediment.

Two wider implications emerge from this study. The first concerns landform resilience to change and paraglacial sediment transfer rates. Without doubt, paraglacial reworking of glacigenic sediment stores has the potential to substantially modify landsurfaces and sediments during and following deglaciation. Minimum rates of ground surface lowering on the Feegletscher Nord lateral moraine have averaged c. 50-100 mm $\mathrm{a}^{-1}$ since ice retreat in AD 1922 (Curry et al., 2005). These rates are similar to those calculated for sites in western Norway (Ballantyne and Benn, 1994; Curry, 1999), though greatly exceed 'normal' erosion rates in other settings (Young and Saunders, 1986), emphasising the extreme rapidity of geomorphic change and sediment transfer on steep, sediment-mantled slopes associated with paraglaciation ( $c f$. Church and Ryder, 1972; Church and Slaymaker, 1989; Harbor and Warburton, 1993). Yet even within an active paraglacial setting, given favourable lithological conditions, moraine slopes, such as those observed in the lateral-terminus area of the Feegletscher Nord, are able to stand at steep angles in a quasi-stable form on a decadal timescale, resisting wholesale removal and reworking, and delaying the release of glacigenic sediment into the proglacial zone and paraglacial sediment cascade. Thus, while some models of primary paraglacial system behaviour indicate activity rates declining rapidly from a peak at the time of deglaciation (e.g. Matthews, 1992), paraglacial sediment movement within the glacigenic sediment-mantled slope landsystem may in many cases peak shortly after, rather than immediately after deglaciation.

Moreover, temporary, quasi-stable storage of glacigenic sediments in high-angle moraines such as those observed in this study is one of several processes likely to 
disrupt the simple, monotonic exponential decline of paraglacial sediment transfer rates and add a stochastic element to the timing of forefield sediment delivery by non-glacial processes. Significant levels of paraglacial reworking can take place in primary paraglacial systems some time after deglaciation in response to non-glacial extrinsic perturbations (Ballantyne, 2002b) and as this study demonstrates, where lithological conditions are favourable. Storage of sediments in moraine sequences can prevent release of glacigenic material by non-glacial processes for several decades following deglaciation. In general, the postglacial disintegration processes of morainic deposits remain poorly understood (e.g. Sletten et al., 2001), and the ability of moraine slopes to resist wholesale disintegration immediately following deglaciation, as observed in this study, suggests that postglacial moraine disintegration and associated sediment supply to forefield areas is not a simple linear process.

A second implication relates to the sensitivity of steep, recently deglaciated moraine slopes to future climate change. Clearly, the relevance of the paraglacial concept is particularly evident in the context of recent retreat of mountain glaciers and climatic amelioration. In contrast to the established use of geophysical and geotechnical approaches in the assessment of periglacial slope problems (e.g. Harris et al., 2001, 2003; Harris, 2005), the application of engineering geology approaches and solutions to paraglacial slope problems is an under-developed research field, despite a growing awareness of non-glacial slope hazards associated with recent glacier retreat (e.g. Evans and Clague, 1994; Haeberli et al., 1997; Holm et al., 2004; Huggel et al., 2004; Chiarle et al., 2007). In this study standard engineering techniques have shed light on controls on paraglacial modification of steep moraines. Further geotechnical work may facilitate improved spatial and temporal prediction of paraglacial mass movement on sedimentmantled slopes. Parameters commonly involved in modelling landslide susceptibility include climatic variables, slope morphology, land use and bedrock lithology. The research presented here highlights the potential role that clast form and fabric may play in enhancing the stability of steep moraine slopes, factors which should be included in landslide (especially debris flow) hazard assessment, monitoring and modelling on steep, glacigenic sediment mantles.

\section{Conclusion}


Although paraglacial reworking of sediments clearly has the capacity to induce slope instability and the movement of large volumes of sediment, given favourable lithological conditions, moraine slopes, such as those observed in the lateral-terminus area of the Feegletscher Nord, are able to stand at steep angles in a quasi-stable form on a decadal timescale. The current slope gradients of the lateral moraine reflect the mechanisms of original emplacement, postglacial (paraglacial) modification, including translational failure, geotechnical properties, stratification and fabric, and high angles of dilation necessary for shallow translational shear to occur on the proximal slopes. Results from the shear box testing suggest (i) that the distal and proximal debris slope angles are similar to the critical effective angles of friction for disturbed samples, and (ii) that a distal slope dip in fabric, throughout the undisturbed moraine, may assist in allowing proximal slopes to exceed peak effective angles of friction measured for disturbed samples in the laboratory. We propose a conceptual model, based on shallow translational shear failure, to explain the mechanisms that enable the preservation of distal, debris and very steep proximal slopes on the Feegletscher Nord and other similar moraines. However, detailed examination of in situ fabric samples from steep slope segments would be required to evaluate this model further, and it is difficult to envisage from a logistical point of view, how in situ fabric of these steeper slope segments could be quantitatively assessed. Detailed fabric analysis of actively forming lateral moraines at contemporary ice margins may provide additional information without the same level of logistical difficulty, although such studies would be unable to assess the role of factors such as glacifluvial reworking, removal of ice buttressing forces and enhanced paraglacial activity during deglaciation. The role of lithology and fabric in allowing steep slopes to exist in quasi-stable form requires further consideration from both a geomorphological point of view and by those considering the susceptibility of recently deglaciated terrain to mass movement hazards; wholesale slope instability is clearly not always an inevitable and immediate consequence of deglaciation and associated paraglacial activity.

\section{Acknowledgements}

This research was supported by a Nuffield Foundation Newly-Appointed Lecturer award to AMC. The authors thank James Loring for field assistance, Reynald Delaloye 
and Benedikt Schnyder for archive photography and site information, Peter Coates for technical support and Robyn Langdon for assistance with laboratory testing.

\section{References}

Ballantyne, C.K. 1982. Aggregate clast form characteristics of deposits at the margins of four glaciers in the Jotunheimen Massif, Norway. Norsk Geografisk Tidsskrift, 36, 103-113.

Ballantyne, C.K. 1995. Paraglacial debris cone formation on recently-deglaciated terrain. The Holocene, 5, 25-33.

Ballantyne, C.K. 2002a. Paraglacial geomorphology. Quaternary Science Reviews, 21, 1935-2017.

Ballantyne, C.K. 2002b. A general model of paraglacial landscape response. Holocene, 12, 371-376.

Ballantyne, C.K. \& Benn, D.I. 1994. Paraglacial slope adjustment and resedimentation following recent glacier retreat, Fåbergstølsdalen, Norway. Arctic and Alpine Research, 26, 255-269.

Benn, D.I. \& Ballantyne, C.K. 1994. Reconstructing the transport history of glacigenic sediments: a new approach based on the co-variance of clast form indices. Sedimentary Geology 91, 215-227.

Benn, D.I., Kirkbride, M.P., Owen, L.A. \& Brazier, V. 2005. Glaciated valley landsystems. In: Evans, D.J.A. (ed) Glacial Landsystems. Arnold, London, 372-406.

Bennett, M.R. \& Glasser, N.F. 1996. Glacial Geology: Ice Sheets and Landforms. John Wiley, London.

Bircher W. 1982. Zur Gletscher- und Klimageschichte des Saastales. Glazialmorphologische und dendroklimatologische Untersuchungen. Phyische Geographie, 9, Geographisches Institut der Universität: Zürich.

Chiarle, M., Iannotti, S., Mortara, G. \& Deline, P. 2007. Recent debris flow occurrences associated with glaciers in the Alps. Global and Planetary Change, 56, 123-136.

Church, M. \& Ryder, J.M. 1972. Paraglacial sedimentation: a consideration of fluvial processes conditioned by glaciation. Geological Society of America, Bulletin, 83, 3059-3071. 
Church, M. \& Slaymaker, O. 1989. Disequilibrium of Holocene sediment yield in glaciated British Columbia. Nature, 337, 452-454.

Curry, A..M. 1999. Paraglacial modification of slope form. Earth Surface Processes and Landforms, 24, 1213-1228.

Curry, A.M. 2000. Observations on the distribution of paraglacial reworking of glacigenic drift in western Norway. Norsk Geografisk Tidsskrift, 54, 139-147.

Curry, A.M., Cleasby, V. \& Zukowskyj, P. 2005. Paraglacial response of steep, sediment-mantled slopes to post-'Little Ice Age' glacier recession in the central Swiss Alps. Journal of Quaternary Science, 21, 211-225.

Evans, S.G. \& Clague, J.J. 1994. Recent climatic change and catastrophic geomorphic processes in mountain environments. Geomorphology, 10, 107-128.

GK/SANW \& VAW/ETZH. 2005. The Swiss Glaciers, Yearbooks of the Glaciological Commision of the Swiss Academy of Science (SAS) published by the Labratory of Hydraulics, Hydrology and Glaciology (VAW) of ETH Zürich. No. 1-122 (18812002). http://glaciology.ethz.ch/swiss-glaciers/.

Haeberli, W., Wegmann, M. \& Vonder Mühll, D. 1997. Slope stability problems related to glacier shrinkage and permafrost degradation in the Alps. Eclogae Geologicae Helvetiae, 90, 407-414.

Harbor, J. \& Warburton, J. 1993. Relative rates of glacial and nonglacial erosion in alpine environments. Arctic and Alpine Research, 25, 1-7.

Harris, C. 2005. Climate Change, Mountain Permafrost Degradation and Geotechnical Hazard. In: Huber, U.M., Bugmann, H.K.M. \& Reasoner, M.A. (eds) Global Change and Mountain Regions. Springer, Netherlands, 215-224.

Harris, C., Davies, M.C.R. \& Etzelmüller, B. 2001. The assessment of potential geotechnical hazards associated with mountain permafrost in a warming global climate. Permafrost and Periglacial Processes, 12, 145-156.

Harris, C., Vonder Mühll, D., Isaksen, K., Haeberli, W., Sollid, J.L., King, L., Holmlund, P., Dramis, F., Guglielmin, M. \& Palacios, D. 2003. Warming permafrost in European mountains. Global and Planetary Change, 39, 215-225.

Hoek, E. \& Bray, J.W. 1981: Rock Slope Engineering. $3^{\text {rd }}$ ed. Institute of Mining and Metallurgy. Taylor and Francis, London.

Holm, K., Bovis, M. \& Jakob, M. 2004. The landslide response of alpine basins to postLittle Ice Age glacial thinning and retreat in southwestern British Columbia. Geomorphology, 57, 201-216. 
Hsü, K.J. 1995. The Geology of Switzerland: an introduction to tectonic facies. Princeton University Press, Princeton.

Huggel, C., Haeberli, W., Kääb, A., Bieri, D. \& Richardson, S. 2004. An assessment procedure for glacial hazards in the Swiss Alps. Canadian Geotechnical Journal, 41, 1068-1083.

Matthews, J.A. 1992. The Ecology of Recently Deglaciated Terrain: A Geo-ecological Approach to Glacier Forelands and Primary Succession. Cambridge University Press, Cambridge.

Matthews, J.A. \& Petch, J.R. 1982. Within-valley asymmetry and related problems of Neoglacial lateral moraine development at certain Jotunheimen glaciers, southern Norway. Boreas, 11, 225-247.

Orwin, J.F. \& Smart, C.C. 2004. The evidence for paraglacial sedimentation and its temporal scale in the deglacierizing basin of Small River Glacier, Canada. Geomorphology, 58, 175-202.

Owen, L.A. 1994. Glacial and non-glacial diamictons in the Karakoram Mountans and Western Himalayas. In: Warren, W.P. \& Croot, D.G. (eds) Formation and Deformation of Glacial Deposits. Balkema, Rotterdam, 9-28.

Owen, L.A. \& Derbyshire, E. 1989. The Karakoram glacial depositional system. Geografiska Annaler Supplementband, 76, 33-73.

Röthlisberger, F., Haas, P., Holzhauser, H., Keller, W., Bircher, W., \& Renner, F. 1980. Holocene climatic fluctuations - radiocarbon dating of fossil soils (fAh) and woods from moraines and glaciers in the Alps. Geographica Helvetica, 35, 21-52.

Röthlisberger, F. \& Schneebeli, W. 1979. Genesis of lateral moraine complexes, demonstrated by fossil soils and trunks; indicators of postglacial climatic fluctuations. In: Schlüchter C. (ed) Moraines and Varves. Balkema, Rotterdam, 387419.

Selby, M.J. 1993. Hillslope Materials and Processes, $2^{\text {nd }}$ ed. Oxford University Press, Oxford.

Slatt, R.M. 1971. Texture of ice-cored deposits from ten Alaskan valley glaciers. Journal of Sedimentary Petrology, 41, 828-834.

Sletten, K., Lyså, A., \& Lønne, I. 2001. Formation and disintegration of a high-arctic ice-cored moraine complex, Scott Turnerbreen, Svalbard. Boreas, 30, 272-284.

Small, R.J. 1983. Lateral moraines of Glacier De Tsidjiore Nouve: form, development and implications. Journal of Glaciology, 29, 250-159. 
Swiss Geological Commission. 1980. Carte géologique de la Suisse, 1:500,000. $2^{\text {nd }}$ ed.

Whalley, W.B. 1975. Abnormally steep slopes on moraines constructed by valley glaciers. In: Proceedings of the Midland Soil Mechanics and Foundation Engineering Society Symposium: The engineering behaviour of glacial materials, University of Birmingham, $21^{\text {st }}-23^{\text {rd }}$ April, 1975, 60-66.

Zingg, T. 1935. Beiträge zur Schotteranalyse: Die Schotteranalyse und ihre Anwendung auf die Glattalschotter. Schweizerische Mineralogische und Petrographische Mitteilungen, 15, 39-140.

\section{Figure captions}

Figure 1. Location and geomorphology of the Feegletscher Nord study site, Valais, Switzerland.
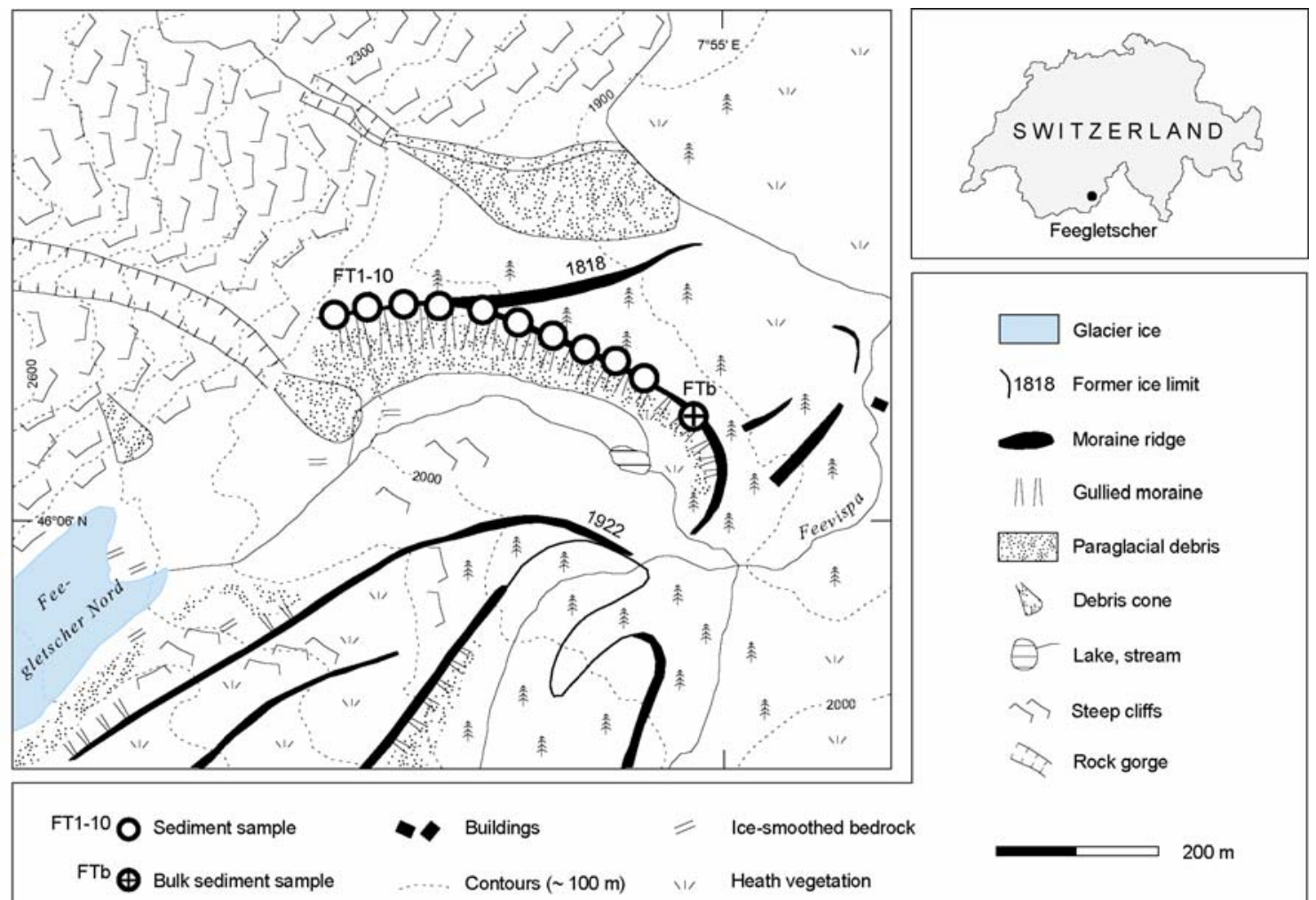

${ }^{\mathrm{T} 1-10} \bigcirc$ Sediment sample
${ }^{\text {FTb }} \oplus$ Bulk sediment sample

Contours $(\sim 100 \mathrm{~m})$

Heath vegetation

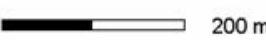




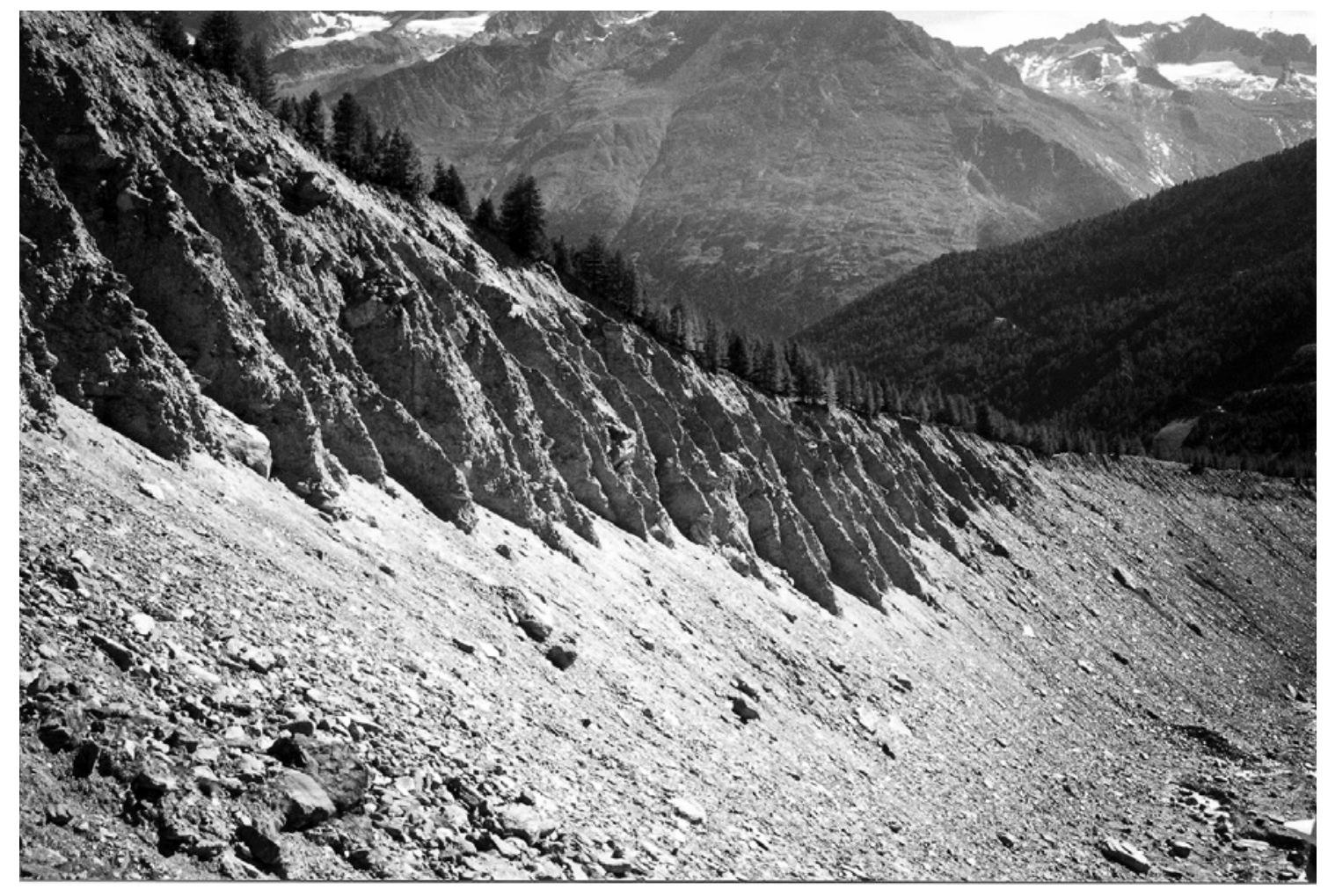

Figure 2. Steep lateral moraine proximal slope incised by paraglacial processes operative since AD 1922 in the Feegletscher Nord forefield area. Debris slides and flows descend across the lower slope surfaces. Note crude, distaldipping stratification exposed in the gully sidewalls. 


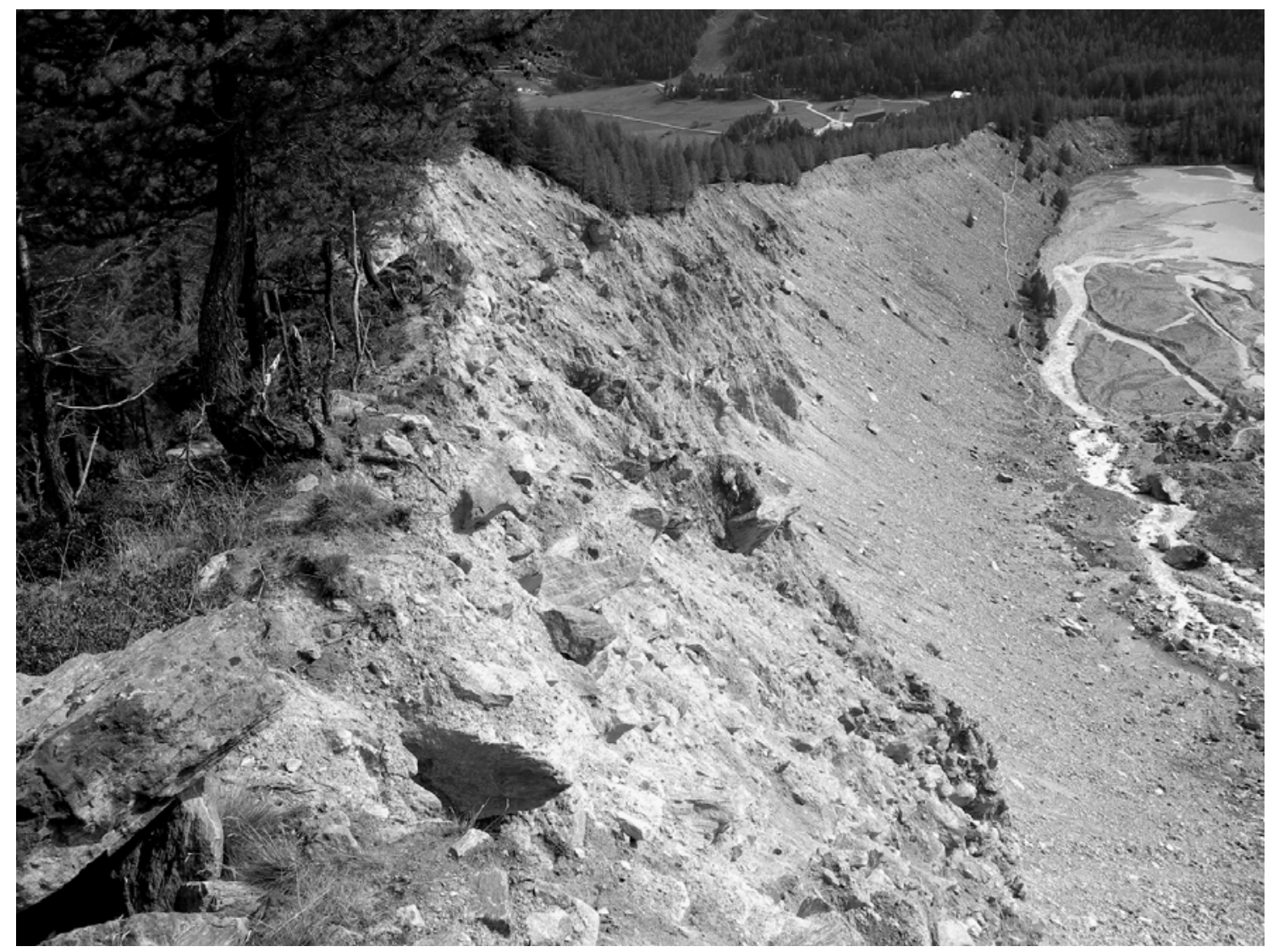

Figure 3. Flat faces of mica-schist boulders within the upper proximal slope dipping at c. $33^{\circ}$ towards the distal slope (left-hand side). 


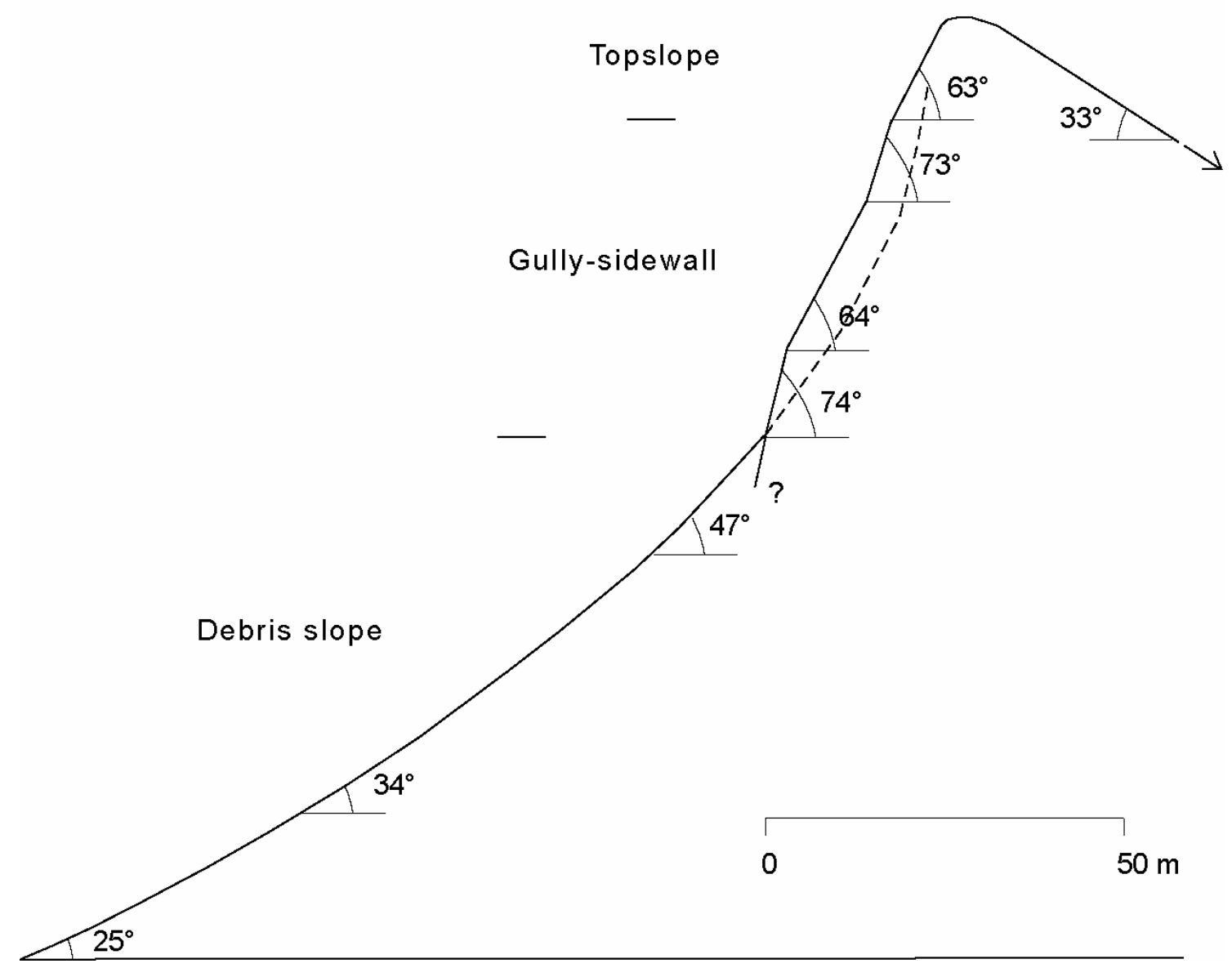

Figure 4. Characterisation of the recently-exposed moraine slopes at Feegletscher Nord, based on average survey measurements: an over-steepened top slope, a middle gullied slope zone, and a lower-angled basal debris sheet. The dashed line indicates the gully floor profile. Only the uppermost part of the distal slope is shown. 


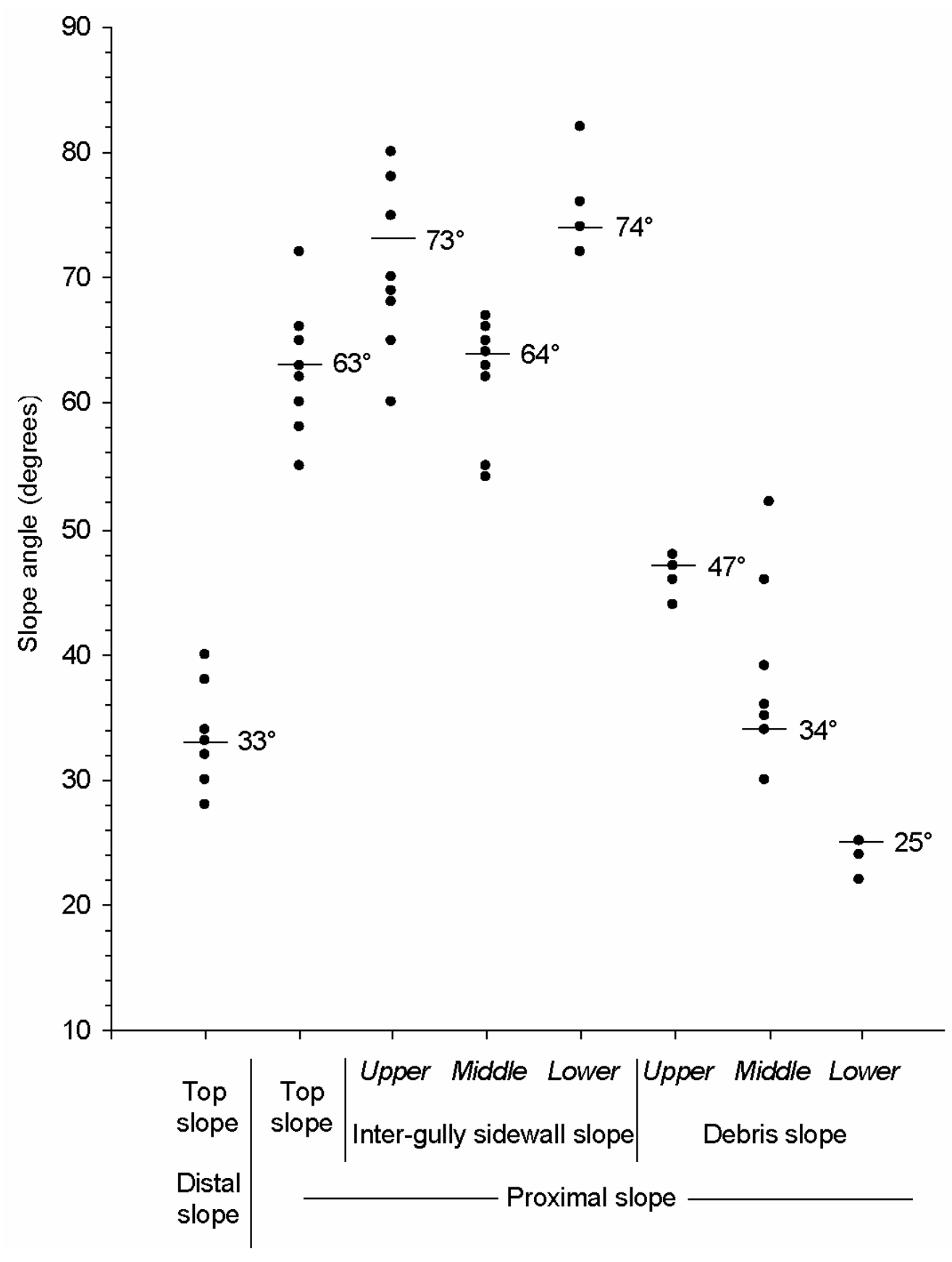

Figure 5. Dispersion diagrams illustrating moraine slope gradient at Feegletscher Nord. Horizontal bars indicate median values. Each closed circle represents one surveyed slope. 


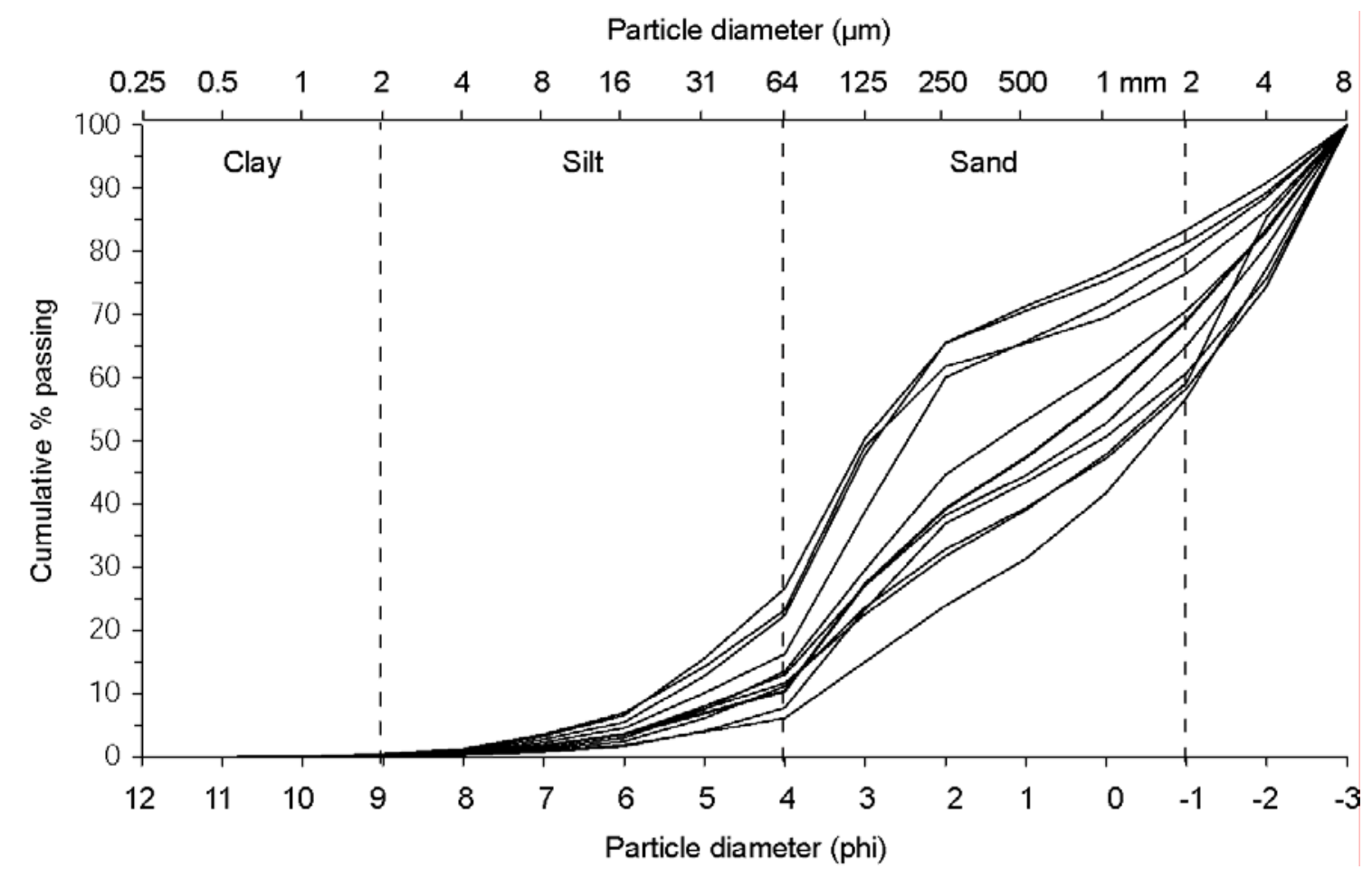

Figure 6. Cumulative particle-size distributions (material finer than $8 \mathrm{~mm} /-3 \Phi$ ) for eleven samples of Feegletscher Nord moraine. The bulk sample is indicated with a bold line. 


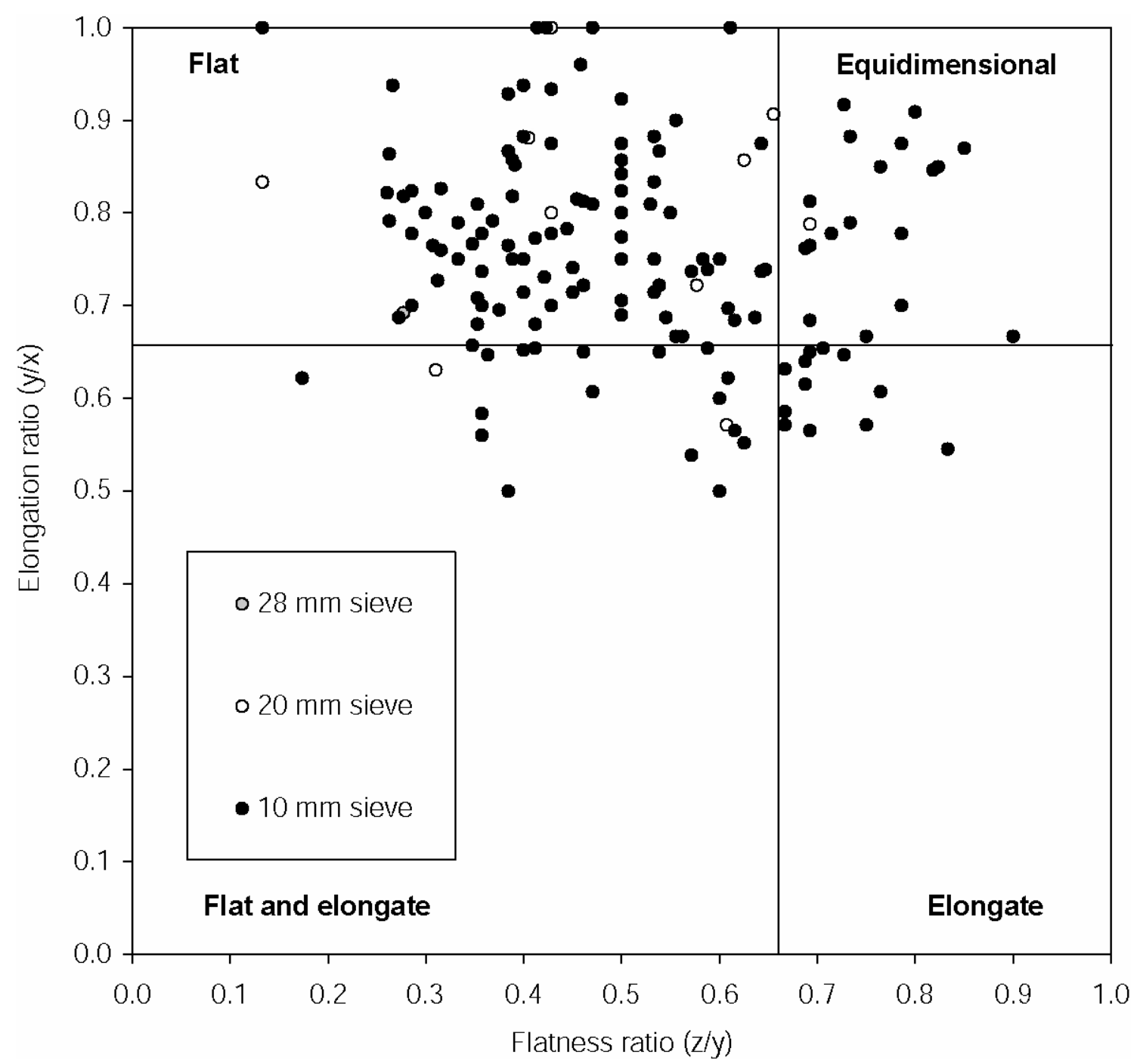

Figure 7. Shape of 167 clasts taken from the Feegletscher Nord moraine bulk sample, summarised according to Zingg's (1935) flatness and elongation ratios. 


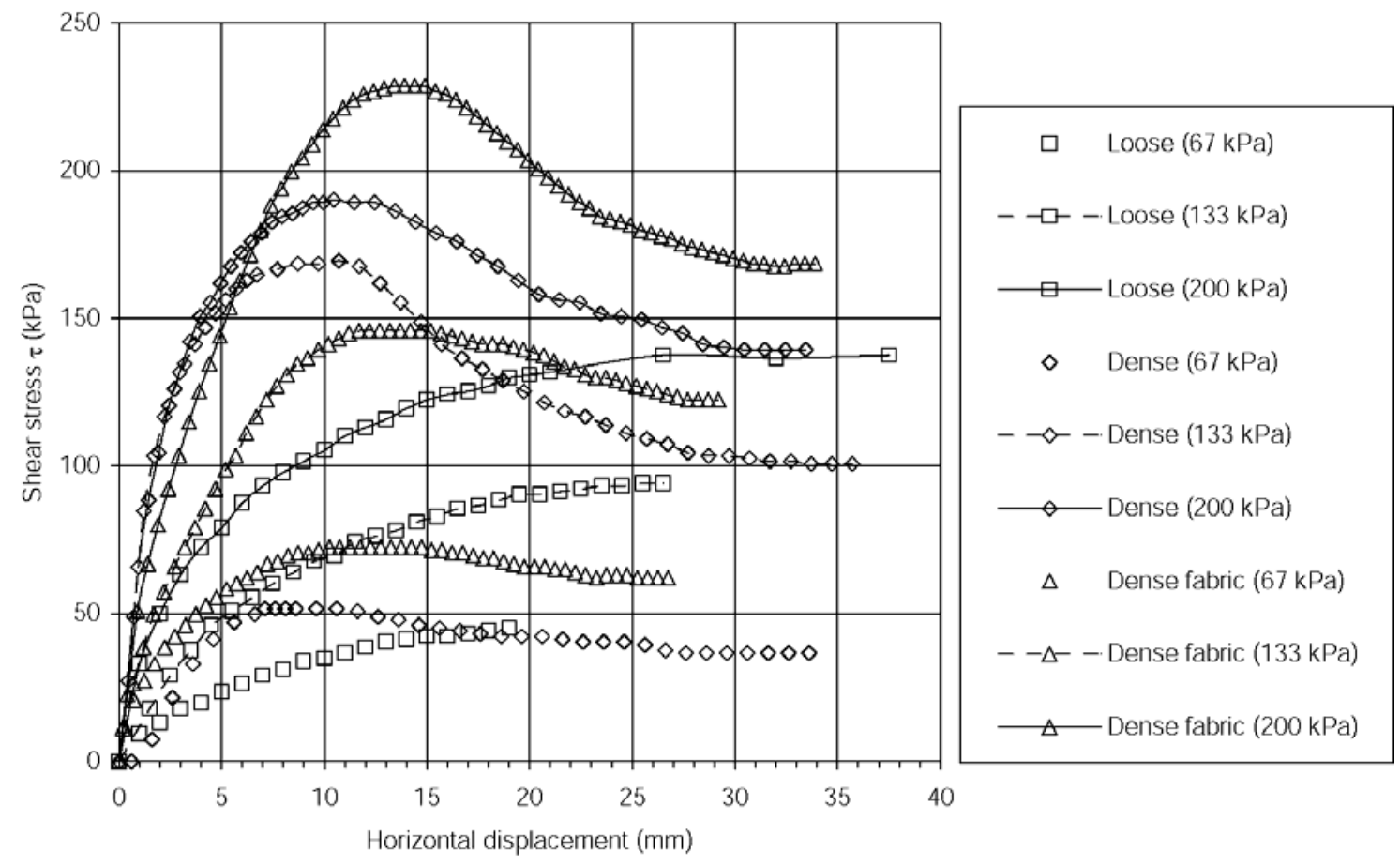

b

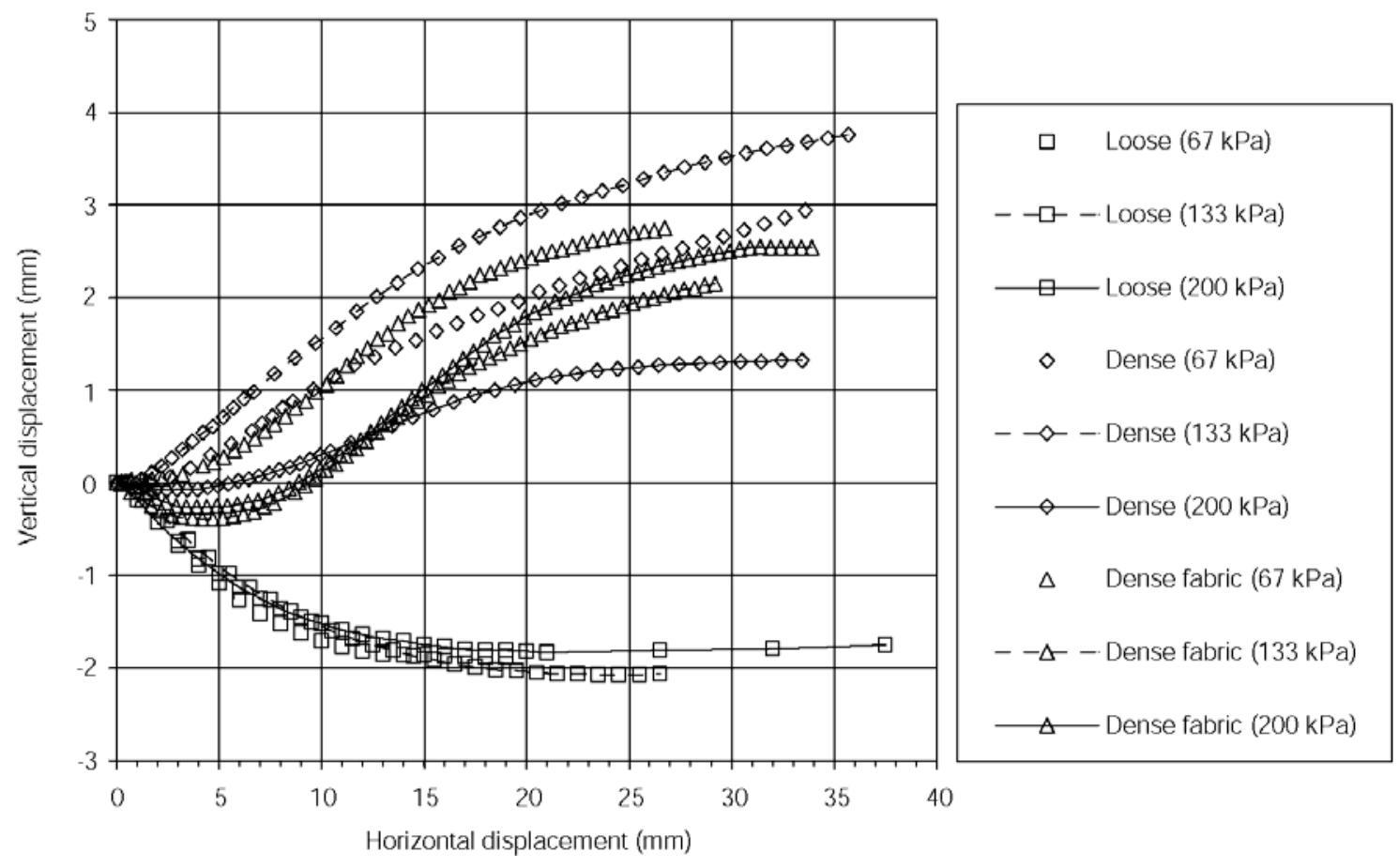




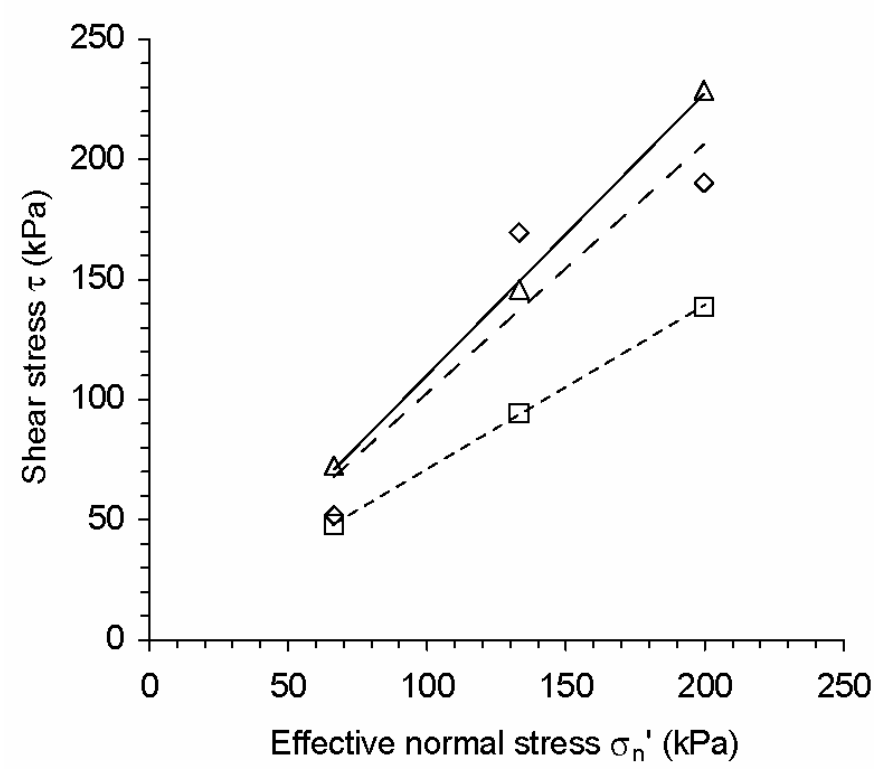

Figure 8. Large shear box tests on the Feegletscher Nord moraine bulk sample, tested 'loose', 'dense' and 'dense fabric' (the latter with a partial fabric perpendicular to the direction of shear). Normal stresses are shown in brackets. (a) Shear stress against horizontal displacement. (b) Vertical displacement against horizontal displacement. (c) Shear stress against effective normal stress. 


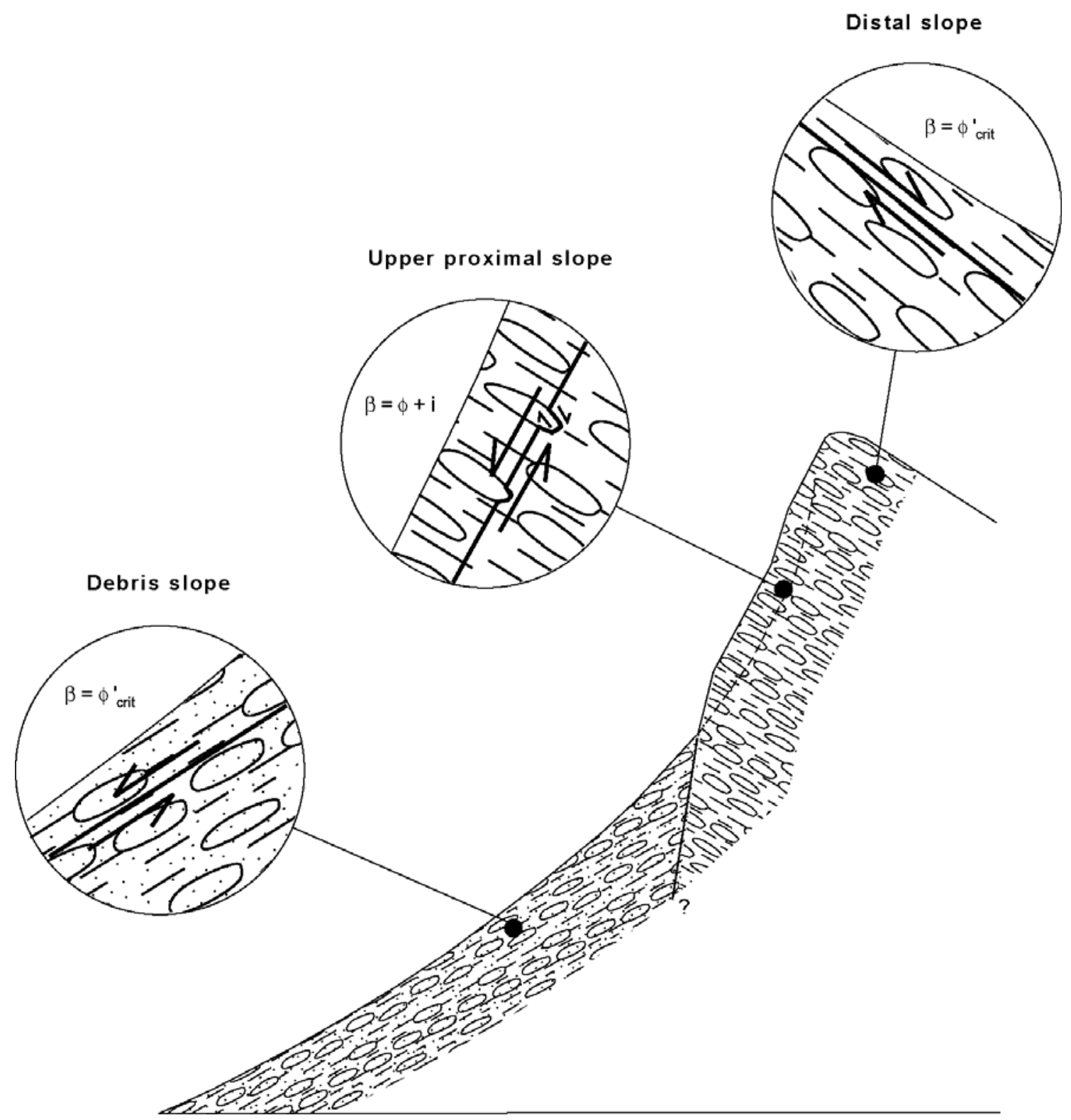

Figure 9. Idealised section through steep moraine slopes showing the influence of clast shape and fabric on shearing resistance and slope angle. Insets show magnified fabric and potential shear surfaces. 